\title{
Physicochemical and bioactive compounds evaluation of Physalis pubescens Linnaeus ${ }^{1}$
}

\author{
Tailise Beatriz Roll Zimmer ${ }^{2 *}$ (D), Deborah Murowaniecki Otero ${ }^{3}$, Rui Carlos Zambiazi ${ }^{4}$
}

\author{
$10.1590 / 0034-737 X 202067060002$
}

\begin{abstract}
Physalis pubescens $L$. is a UFP (unconventional food plant) that produces high quality fruits; however, in Rio Grande do Sul it is still considered a rare species. There is only few information regarding the characterization of these fruits in Brazil, and the main reports of this species are mainly focused on the pharmacology and agronomic conditions of the plant. The aim of this study was to analyze the physical and chemical composition, including bioactive compounds, of Physalis fruits obtained from a spontaneous culture of the southern region of Rio grande do sul. Soluble solids, total titratable acidity, vitamin C, moisture, ash, crude fiber, crude protein, lipids, carbohydrates, total caloric value, carotenoids, phenolic compounds, flavonoids and phenolic acids from pulp and seed were evaluated. It was observed that the fruit has acid characteristics (4.8\%), in addition to a considerable presence of lipids (1.96\%) and carbohydrates (10.85\%), containing high content of carotenoids (171.36 $\mu \mathrm{g} \beta$-carotene. $\left.\mathrm{g}^{-1}\right)$, phenolic compounds $\left(142.83 \mathrm{mg} . E A G .100 \mathrm{~g}^{-1}\right)$ and phenolic acids (38.55 mg EAC. $100 \mathrm{~g}^{-1}$ ). It was possible to observe that the fruits of Physalis pubescens are nutritious, presenting light acidity and they are a rich source of bioactive compounds.
\end{abstract}

Keywords: proximal composition; phenolic compounds; carotenoids.

\section{INTRODUCTION}

Physalis pubescens $L$. is a tree found in subtropical regions that produce fruits that range color from green to yellow, containing many tiny seeds, sweet and slightly acidic juicy and a golden yellow skin (El Sheikha, 2004; Montet et al., 2008). El Sheikha (2010), points out that the flavor of the Physalis fruits is bittersweet and comes close to the flavor of the tomato and pineapple mixture.

The fruits' physicochemical characteristics allow us to evaluate the degree of ripeness, to determine the harvest point, to define forms of postharvest handling and appropriate packaging, and to define storage and processing conditions to obtain its derivatives (Chitarra \& Chitarra, 2005).

The main benefits associated with Physalis consumption are its nutritional composition (important source of vitamins and minerals) as well as the presence of bioactive compounds (carotenoids and phenolic compounds) (Salazar et al., 2008; Valdenegro et al., 2012). According to Kharchoufi et al. (2018) its consumption is linked to health promotion.

Studies with UFP, such as Physalis pubescens L., have become increasingly attractive due to the continuous search for bioactive compounds of natural origin (Fernandes et al., 2019). In addition, the Brazilian biodiversity has great potential for expansion, as there are numerous native and exotic fruits still little economically explored. Due to its appearance, shape and different flavor, Physalis pubescens $L$. fruits have been investigated for better evaluation of their nutritional potential.

According to El Sheikha et al. (2008; 2009) e El Sheikha (2010), Physalis is considered an exotic fruit and it is included in the priority list of many government plans for horticulture and fruit exports, even though it is relatively

\footnotetext{
Submitted on May $15^{\text {th }}, 2020$ and accepted on September $2^{\text {nd }}, 2020$.

${ }^{1}$ This work is part of the Master's Thesis of the first author, with the support of the National Council for Scientific and Technological Development.

${ }^{2}$ Universidade Federal de Pelotas, Departamento de Ciência e Tecnologia Agroindustrial, Pelotas, Rio Grande do Sul, Brazil. zimmertailise@gmail.com

${ }^{3}$ Universidade Federal da Bahia, Departamento de Ciência de Alimentos, Escola de Nutrição, Salvador, Bahia, Brazil. deborah.m.otero@gmail.com

${ }^{4}$ Universidade Federal de Pelotas, Centro de Ciências Químicas, Farmacêuticas e de Alimentos, Pelotas, Rio Grande do Sul, Brazil. zambiazi@gmail.com

*Corresponding author: zimmertailise@gmail.com
} 
unknown in import markets. However, in Egypt, Physalis has been known for a long time, and recently, its economic importance has increased due to its high acceptance for local consumption, mainly in the Arab and European market (El Sheikha, 2004).

By researching and defining the characteristics of these native and exotic fruits, it is possible to promote their commercialization and introduction into the population's food, both through in natura consumption and through the elaboration of derived products (de Almeida et al., 2013).

Even though we have witnessed a growth in the usage and an increase in the value attributed to these regional products, the information available about nutritional potential of Physalis pubescens $L$ fruits is still limited (Souza et al., 2012). The present study had the objective of analyzing the physical and chemical composition, including bioactive compounds, of Physalis fruits obtained from a spontaneous culture of the southern region of Rio Grande do Sul.

\section{MATERIALS AND METHODS}

Physalis pubescens fruits were obtained in their maturity stage (straw-yellow chalice color) visually evaluated, and harvested (approximately 500g of fruits from each tree) from the countryside of Cerrito city (latitude $31^{\circ} 42^{\prime} 36^{\prime \prime}$ and longitude $52^{\circ} 45^{\prime} 39^{\prime \prime}$ ), in the southern west region of Rio Grande do Sul (Figure 1), from 15 spontaneous culture in the period ranging from january to june 2017. Before the evaluation, all collected fruits were mixed and the analyzes were performed in triplicate.

Immediately after being collected, the fruits were washed with filtered water and stored under freezing $\left(-18^{\circ} \mathrm{C}\right)$. For the analysis of bioactive compounds, the fruit was lyophilized (Terroni, Enterprise II, Brazil), macerated to obtain a powder, following the seed separation by a 32 mesh size sieve (Bertel, $500 \mathrm{~mm} / \mu$, Brazil).

The experiments were conducted at the Food Chromatography Laboratory of the Department of Agroindustrial Science and Technology (DCTA) located at FAEM (Eliseu Maciel College of Agronomy) at the Federal University of Pelotas, Capão do Leão, Campus / RS.

\section{Physicochemical and proximal composition}

The determination of soluble solids was performed using a digital refractometer (Palette Atago, A52444, Japan) and the results were expressed in ${ }^{\circ}$ Brix according to the method of AOAC (2012). The hydrogen potential ( $\mathrm{pH}$ ) was determined according to the methodology described by Zambiazi (2010), using benchtop pH meter (Hanna, Hi 2221, Brazil).

Total acidity was determined according to the methodology described by AOAC (2012), by titration of the sample with $0.1 \mathrm{~N}$ sodium hydroxide $(\mathrm{NaOH})$ solution, expressing the results in percentage. Moisture was determined according to the methodology described by AOAC (2012), where a sample was placed in an oven at $105{ }^{\circ} \mathrm{C}$ until constant weight, expressing the results in percentage.

Ash content was determined in muffle oven according to the AOAC (2012) methodology, by incinerating the sample at $550{ }^{\circ} \mathrm{C}$, and expressing the results in percentage. Crude fiber was obtained after acid and alkaline digestion of the dried and degreased sample, following the methodology described by AOAC (2012). The fiber content was calculated by the difference between the sample dried weight and the ash weight, expressing the results in percentage.

The total protein content determination was performed using the Micro-Kjeldhal method, according to the methodology described by AOAC (2012), expressing the results in percentage. Lipid determination followed the Bligh \& Dyer (1959) methodology, using 2:1 (v / v) chloroform: methanol as the extraction mixture, expressing the results in percentage.

The total carbohydrate content was determined according to the Brazilian Legislation (2003), and the results were expressed in percentage. According to Brazilian Legislation (2003), the total caloric value was calculated by adding the calories generated by the major nutrients metabolism, and the results were expressed in Kcal.g-1.

\section{Bioactive composition}

The determination of the samples' total carotenoid content was performed by the spectrophotometric method described by Rodriguez-Amaya et al. (2001). Readings were taken on a Uv-vis spectrophotometer (Jenway, 6705 Uvvis, Spain), using a wavelength of $450 \mathrm{~nm}$, expressing the results in $\mu \mathrm{g}$ of $\beta$-carotene. $\mathrm{g}^{-1}$ of lyophilized sample (equation 1).

Carotenoid content $\left(\mu g \beta\right.$-carotene. $\left.g^{-1}\right)=\frac{A \times B \times 10^{6}}{2500 \times 100 \times P}$ Equation 1.

Of which: A: wavelength absorbance of $450 \mathrm{~nm}$; B: extract volume $(\mathrm{mL})$; P: sample weight $(\mathrm{g})$.

Initially, an extract was obtained using a 1: 20 hydroalcoholic solution (sample: $80 \%$ ethanol). The extracts were stored at $4{ }^{\circ} \mathrm{C}$ for 24 hours, and centrifuged (Sorvall, RC-5C, Alemanha) at $2800 \mathrm{xg}$ for 20 minutes. The supernatant was removed, it was collected in an amber flask and frozen until the moment of the analysis (Repo \& Encina, 2008).

The quantification of phenolic compounds was performed according to Singleton \& Rossi (1965), by colorimetric reaction using Folin Ciocalteau reactive 
solution, with the corresponding reading of the mixture in a spectrophotometer (Jenway, 6705 Uv-vis, Spain), at a wavelength of $725 \mathrm{~nm}$. A standard curve of gallic acid (0.4 to $2.0 \mathrm{mg} . \mathrm{L}^{-1}$ ) was used and the results were expressed in $\mathrm{mg}$ of gallic acid, equivalent per $100 \mathrm{~g}$ sample (mg EAG.100g-1 dry basis).

The flavonoid content was obtained according to the method proposed by the Chinese Pharmacopoeia Commission (2010), with few modifications. $1 \mathrm{~mL}$ of hydroalcoholic extract was reacted with $100 \mu \mathrm{L}$ of $5 \%$ sodium nitrite solution under stirring for 6 minutes, and then $100 \mu \mathrm{L}$ of $10 \%$ aluminum chloride solution was also added under stirring and kept in rest for another 5 minutes. After this time, $1 \mathrm{~mL}$ of $1 \mathrm{M}$ sodium hydroxide solution and $2 \mathrm{~mL}$ of $80 \%$ ethanolic solution were added. Absorbance reading was performed using Uv-vis spectrophotometer (Jenway, $6705 \mathrm{Uv}$-vis, Spain) at a wavelength of $415 \mathrm{~nm}$. Quantification was performed by using a standard curve on quercetin ( 0 to $\left.0.15 \mathrm{mg} . \mathrm{L}^{-1}\right)$. Results were expressed in $\mu \mathrm{g}$ of quercetin equivalent per gram of dry base sample $\left(\mu \mathrm{gEQ} \cdot \mathrm{g}^{-1}\right)$.

The phenolic acid content was obtained according to Mazza et al. (1999), with few modifications. Aliquots of $250 \mu \mathrm{L}$ of hydroalcoholic extract plus $250 \mu \mathrm{L}$ of the acidified ethanol solution $(0.1 \%$ hydrochloric acid in ethanol $95 \%)$ and $4.55 \mathrm{~mL}$ of $2 \%$ hydrochloric acid solution were used. Absorbance reading was performed at $320 \mathrm{~nm}$ on a Uv-vis spectrophotometer (Jenway, 6705 Uv-vis, Spain). Quantification was performed by using a standard curve of caffeic acid ( 0 to $200 \mathrm{mg} . \mathrm{L}^{-1}$ ) and the results were expressed in $\mu \mathrm{g}$ of caffeine acid equivalent per gram of dry sample (mg EAC. $\left.100 \mathrm{~g}^{-1}\right)$.

Ascorbic acid (vitamin C) content was determined using the Lorenz-Steves titration method described by Zambiazi (2010). The determination is based on the reducing action of ascorbic acid by using $0.01 \mathrm{~N}$ iodine standard solution, employing $0.01 \mathrm{~N}$ sodium thiosulfate and $0.5 \%$ starch solution as an indicator. Results were expressed in $\mathrm{mg}$ of L-ascorbic acid per $100 \mathrm{~g}$ of dry sample, according to equation 2 .

Vitamin $\mathrm{C}=\frac{Y \times 0.88}{P}$

Equation 2.

Where: $\mathrm{Y}=$ (total volume of iodine solution $\mathrm{x}$ solution factor) - (volume of thiosulfate solution $\mathrm{x}$ solution factor); $\mathrm{P}=$ sample weight $(\mathrm{g}) ; 1 \mathrm{~mL} 0.01 \mathrm{~N}$ iodine solution $=0.88 \mathrm{mg}$ ascorbic acid.

The analyzes were performed in triplicate and the results were evaluated using descriptive statistical analysis of the data by using analysis of variance (ANOVA) and Tukey's test or t test $(\mathrm{p}<0.05)$ for samples with normal data distribution. The Mann Whitney nonparametric test ( $\mathrm{p}<$ $0.05)$ was used for asymmetric data that did not show normality.

\section{RESULTS AND DISCUSSIONS}

The fruits differ in composition from each other, since intrinsic and extrinsic factors interfere in the concentration

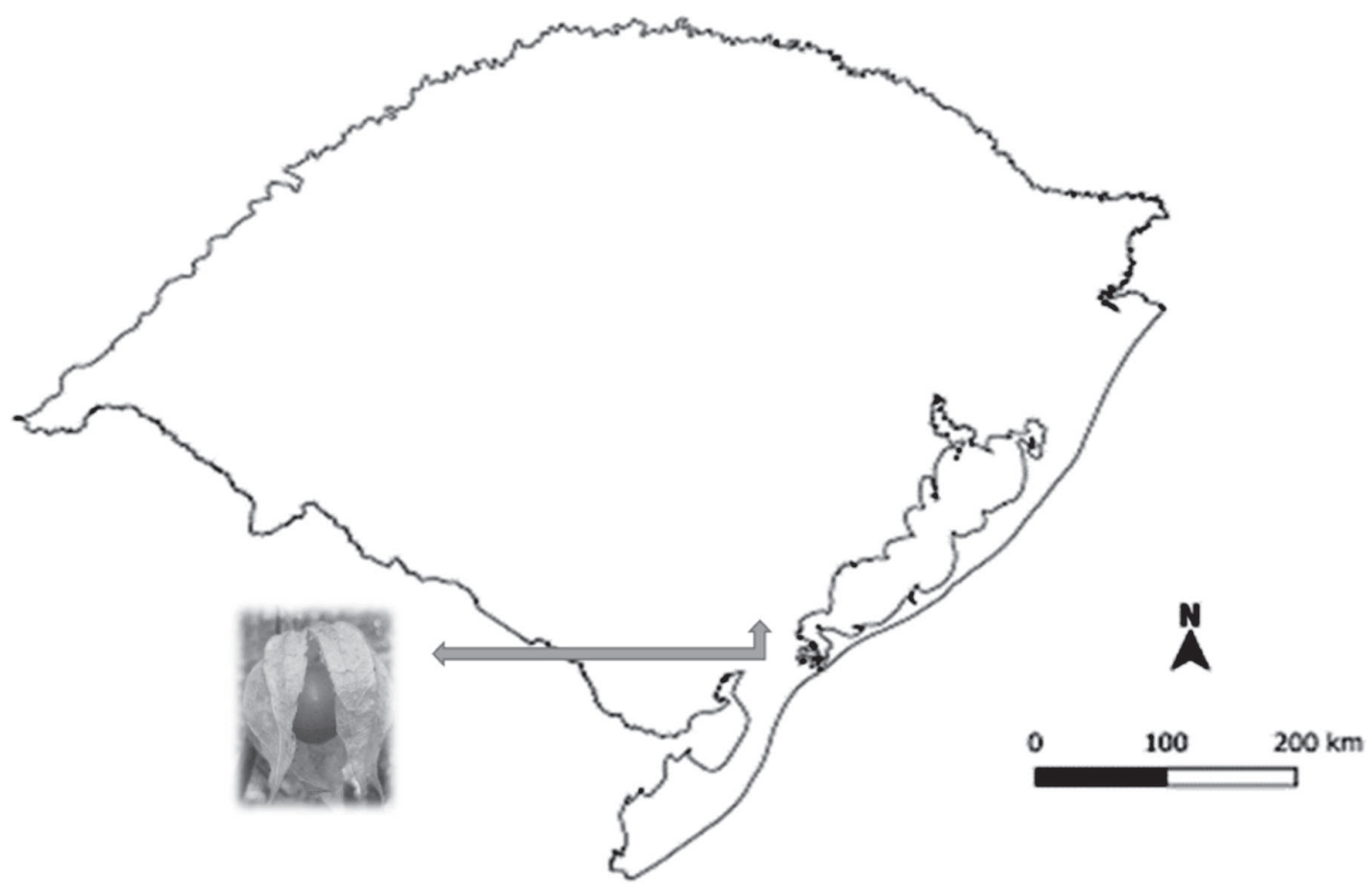

Figure 1: Map of Rio Grande do Sul indicating the place where the samples were collected.

Rev. Ceres, Viçosa, v. 67, n.6, p. 432-438, nov/dec, 2020 
of nutritional and bioactive compounds. Among the main factors are the type of fruit and the variety, the soil, the climatic conditions, the degree of ripeness, each region and each cultivar will present different peculiarities and therefore the need for this study. The data of the proximal and physicochemical composition of Physalis pubescens $L$. fruits are shown in Table 1.

The fruit presented a $\mathrm{pH}$ of 3.76 , thus being considered an acid fruit. This value was close to the values described in the literature for fruits of the same genus, which varies between 3.3 and 3.8 (El Sheikha et al., 2008; El Sheikha et al., 2010; Curi et al., 2018). Higher $\mathrm{pH}$ values (4.72) were reported by Мамедов еt al. (2017). According to El Sheikha et al. (2008), the low pH value indicates strong fruit acidity, which may be linked to the presence of freeforms of organic acids.

The total titratable acidity of Physalis fruit was $4.80 \%$, and the SS / TA ratio was $1.5 \%$. It was observed that the high acidity of the fruits corresponded to the low $\mathrm{pH}$ value. The acidity content was higher than the one reported by Curi et al. (2018), 1.59\%; by El Sheikha et al. (2008), 1.43\%; and by Silva (2013), from 0.18 to $2.57 \%$, all values reported for Physalis pubescens $L$. fruits. The ratio between total titratable acidity and soluble solids content (SST / ATT) is usually related to the ripeness and conservation status of the fruit (Chitarra \& Chitarra, 2005).

The average of soluble solids content was $7.30^{\circ}$ Brix, being similar to those described for fruits of Physalis pubescens by Silva (2013) (6.52 $\left.{ }^{\circ} \mathrm{Brix}\right)$ and by Curi et al. (2018) $\left(8.33^{\circ}\right.$ Brix); however, it was lower than the values found by М а м е д о в et al. (2017) $\left(9.65^{\circ}\right.$ Brix). According to Resende et al. (2010), soluble solids content is related to fruit quality and may vary between cultivars and environmental conditions, besides being an indicative of fresh fruit sweetness.

Table 1: Physicochemical composition of Physalis pubescens $L$. fruits

\begin{tabular}{lc}
\hline Evaluated parameters & Average content \pm SD * \\
\hline pH & $3.76 \pm 0.02$ \\
Soluble solids ( ${ }^{\circ}$ Brix) & $7.30 \pm 0.06$ \\
Total titratable acidity $(\%)$ & $4.80 \pm 0.07$ \\
SS/AT ratio (\%) & $1.5 \pm 0.01$ \\
Moisture (\%) & $79.35 \pm 1.10$ \\
Ashes (\%) & $2.18 \pm 0.20$ \\
Crude fiber (\%) & $3.58 \pm 0.30$ \\
Protein (\%) & $2.08 \pm 0.14$ \\
Lipids (\%) & $1.96 \pm 0.16$ \\
Carbohydrates $(\%)$ & 10.85 \\
\hline
\end{tabular}

Total caloric value $\left(\mathrm{kcal} 100 \mathrm{~g}^{-1}\right) \quad 69.36$

* Average values obtained from the analysis of 3 repetitions; $\mathrm{SD}=$ standard deviation; $\mathrm{SS}=7.3 \% ; \mathrm{AT}=4.8 \%$.
The moisture content of the in natura fruit (79.35\%) is consistent with what is reported by El Sheikha et al. (2008), 81.34\% in Physalis pubescens; and by Santos et al. (2017), $80.74 \%$ in Physalis peruviana. The high moisture content is found to be a characteristic of the family in question, besides being related to the stability, quality and composition of the fruits, where foods with high moisture could deteriorate faster during storage (Vallilo et al., 2008).

The average ash content of $2.18 \%$ was lower than the one reported by El Sheikha et al. (2008), 5.58\% for fruit and $7.01 \%$ for juice, both from Physalis pubescens; and it was higher than those reported by Oliveira et al. (2011), $0.65 \%$ in Physalis angulata; and by Y1ld1z et al. (2015) of $2.98 \%$ in Physalis peruviana. In a food sample the ash content represents the total mineral content (Zambiazi, 2010).

The $2.08 \%$ of protein content of Physalis fruits is in accordance with the content of most native fruits. A varied content of protein for Physalis is reported by Oliveira et al. (2011), 0.85\%; by Y1ld1z et al. (2015), 1.66\%; and by Santos et al. (2017), 5.37\%. Fruits and vegetables provide little protein, about 1 to $2 \%$ of their weight; however, they should not be disregarded (Monteiro, 2009).

The fiber content of $3.58 \%$ was lower than what was reported by El Sheikha et al. (2008), 5.8\% in Physalis pubescens, and by Ramadan (2011), 4.9\% for Physalis peruviana; and the values were higher than the content in Physalis angulata, reported by Oliveira et al. (2011) with only $0.84 \%$.

The average of lipid content in these fruits, $1.96 \%$, was higher than what was found by El Sheikha et al. (2010): 1\% in Physalis pubescens; by Y1ldiz et al. (2015), $0.18 \%$ in Physalis peruviana; by Santos et al. (2017), 0.99\% in Physalis peruviana; and by Oliveira et al. (2011), $0.59 \%$ in Physalis angulata. According to Ramadan \& Mörsel (2003), Physalis fruit has $2 \%$ oil, with $1.8 \%$ present in the seed and the other $0.2 \%$ in the skin and pulp.

The fruits' carbohydrate content was $10.85 \%$. This content was also consistent with what is reported by Santos et al. (2017), 10.92\% in Physalis peruviana; and lower than what was reported by Yýldýz et al. (2015), 13.86\% also in Physalis peruviana. These compounds stand out for being an important source of energy (Sapata et al., 2006).

The caloric content of the Physalis was $69.36 \mathrm{kcal} .100 \mathrm{~g}^{-}$ ${ }^{1}$ of fruit. This value was higher than the one reported in the review by Rufato et al. (2013), $49 \mathrm{kcal} 100 \mathrm{~g}^{-1}$ of Physalis (Flóres et al., 2000); it was similar to the values found in Physalis peruviana L. by the National Research Council (1989), $73 \mathrm{kcal} 100 \mathrm{~g}^{-1}$, and by Repo \& Encina (2008), 76.8 kcal. $100 \mathrm{~g}^{-1}$; and it was higher than the ones reported by Flóres et al. (2000) and Osorio \& Roldan (2003), 49 kcal.100g-1 as shown in the review of Puente et al. (2011); by Joshi \& Joshi (2016), $44.29 \mathrm{Kcal} 100 \mathrm{~g}^{-1}$ of Physalis peruviana; and by El Sheikha et al. (2008), $49{\mathrm{kcal} .100 \mathrm{~g}^{-1}}^{-1}$ 
in Physalis pubescens L. According to Vallilo et al. (2008), that characterized fruits of Campomanesia xanthocarpa $\mathrm{O}$. Berg, the low caloric value $\left(57.3 \mathrm{kcal} .100 \mathrm{~g}^{-1}\right)$ is mainly due to the high moisture content.

Smaller fruits, such as Physalis, have a range of macro and micronutrients, as well as bioactive compounds that can bring benefits to human health when consumed regularly (Vizzotto, 2012). Bioactive compounds are considered micronutrients, which usually occur in small amounts in foods and vary widely in structure and chemical function. Among the main bioactive compounds are carotenoids, phenolic compounds and ascorbic acid. The main bioactive compounds of Physalis pubescens $L$. are shown in Table 2.

Significant difference was observed on the content of bioactive compounds between the pulp and seed variables. For all parameters analyzed, the pulp presented the highest values.

The carotenoid content in the pulp was $171.37 \mu \mathrm{g}$ $\beta$-carotene. $\mathrm{g}^{-1}$. Wen et al. (2017) report lower levels of carotenoids and carotenoid esters in Physalis pubescens, which ranged from $12.8 \mu \mathrm{g} \beta$-carotene. $\mathrm{g}^{-1}$ to $13.8 \mu \mathrm{g}$ $\beta$-carotene. $\mathrm{g}^{-1}$ of fruits, beeing $\beta$-carotene the predominant carotenoid, comprising $36-40 \%$ of the total carotenoids present in the fruit. $\beta$-carotene was the predominant carotenoid also reported in other Physalis species, especially yellow ones (Wen et al., 2017).

The average content of phenolic compounds in Physalis pubescens pulp was 142.83 mg EAG. $100 \mathrm{~g}^{-1}$, it was higher than the values reported by Silva et al. (2016), 112.37 mg EAG. $100 \mathrm{~g}^{-1}$ of Physalis pubescens fresh fruits, and by Curi et al. (2018), 25.54 mg EAG.100g ${ }^{-1}$ of Physalis pubescens. М а м до в et al. (2017) reported $318 \mathrm{mg}$ EAG.100g-1 dry weight content in Physalis pubescens. According to the authors, this species is the richest in polyphenols, followed by Physalis peruviana. The authors emphasize that the polyphenol content is specific to each species of the subtropical climate.

The average flavonoid content was $0.14 \mu \mathrm{g}$ EQ. $\mathrm{g}^{-1}$ and for phenolic acids an average content of $38.55 \mu \mathrm{g}$ EAC. $\mathrm{g}^{-1}$.
When evaluating the flavonoid content in Physalis peruviana, Santos et al. (2017) reported the average content of $8.23 \mathrm{mg} .100 \mathrm{~g}^{-1}$ on wet basis; Antunes et al. (2016) reported $0.032 \mathrm{mg} \mathrm{g}^{-1}$ on wet basis; and Correia et al. (2017) presented $0.340 \mathrm{mg}$ QE. $100 \mathrm{~g}^{-1}$ in wet weight. Hassanien (2011) reports much higher values in Physalis peruviana, in extracts obtained by supercritical carbon dioxide extraction, $234 \mathrm{mg} \cdot \mathrm{g}^{-1}$ of in natura fruit.

Flavonoids are comprised of a group of phenolic compounds that contribute to the sensory quality of fruits, including astringency and bitterness (Vendramini \& Trugo, 2004; Vasco et al., 2008). Phenolic acids are characterized by having a benzene ring, a carboxylic group and one or more hydroxyl and / or methoxyl groups in the molecule, granting antioxidant properties on fruits and vegetables (Soares, 2002) as well as on the consumer's organism.

The phenolic acid content found in the present study was $38.55 \mathrm{mg}$ EAC. $100 \mathrm{~g}^{-1}$, which is lower than the one reported by Rockenbach et al. (2009), $346.1 \mathrm{mg} .100 \mathrm{~g}^{-1}$ on dry basis in Physalis peruviana $L$; and by Zavaleta et al. (2005), 3.85 mg EAC.g ${ }^{-1}$ dry weight Physalis pubescens. Deng et al. (2016) reported that flavonoids and caffeic acid derivatives are the main compounds of Physalis pubescens $L$, which are responsible for contributing to health benefit.

Through the analysis carried out in this study, the fruits' content of vitamin C was $6.07 \mathrm{mg}$ of acid. L-ascorbic. $100 \mathrm{~g}^{-1}$ on a dry basis, which is very similar to that found by М а м е д о в et al. (2017), $9.9 \mathrm{mg}$ of ascorbic acid.100 $\mathrm{g}^{-1}$ of fruit on a dry basis. Lower contents were reported by El Sheikha et al. (2010), 0.4g.100 $\mathrm{g}^{-1}$ of ascorbic acid in dry matter in Physalis pubescens.

Puente et al. (2011) point out that ascorbic acid is a water-soluble vitamin, so in fruits with water content higher than $50 \%$, it is largely present. According to М а м е д о в et al. (2017), Physalis fruits that are native from regions with lower temperatures presents a lower content of ascorbic acid than the ones grown in warmer temperatures. This could partially explain the vitamin $\mathrm{C}$ content found in the Physalis fruits evaluated in this study.

Table 2: Content of pulp and seed of Physalis pubescens $L$ bioactive compounds

\begin{tabular}{|c|c|c|}
\hline \multirow{2}{*}{ Evaluated Parameters* } & \multicolumn{2}{|c|}{ Average content \pm standard deviation } \\
\hline & Pulp * & Seed * \\
\hline Carotenoids ( $\mu \mathrm{g} \beta$-caroteno. $\mathrm{g}^{-1}$ ) & $171.36^{\mathrm{a}} \pm 24.5$ & $22.53^{\mathrm{b}} \pm 5.2$ \\
\hline Phenolic compounds (mg EAG.100g $\mathrm{g}^{-1}$ ) & $142.83^{\mathrm{a}} \pm 0.6$ & $50.03^{\mathrm{b}} \pm 2.2$ \\
\hline Flavonoids ( $\mu \mathrm{g}$ EQ. $\left.\mathrm{g}^{-1}\right)$ & $0.14^{\mathrm{a}} \pm 0.002$ & $0.04^{b} \pm 0.002$ \\
\hline Phenolic acids (mg EAC. $100 \mathrm{~g}^{-1}$ ) & $38.55^{\mathrm{a}} \pm 3.6$ & $11.91^{\mathrm{b}} \pm 2.7$ \\
\hline Vitamin C (mg of L-ascorbic acid. $\left.100 \mathrm{~g}^{-1}\right)$ & $6.07^{\mathrm{a}} \pm 0.45$ & $0.70^{b} \pm 0.1$ \\
\hline
\end{tabular}

ANOVA test of variance and the Tukey test $(\mathrm{p}<0.05)$ were used for phenolic compounds, flavonoids and vitamin $\mathrm{C}$ data; the Mann Whitney test $(\mathrm{p}<0.05)$, for $\mathrm{p}$ values of 0.049535 , was used for carotenoids and phenolic acids data; Means followed by the same letter on the line do not differ statistically; * dry basis.

Rev. Ceres, Viçosa, v. 67, n.6, p. 432-438, nov/dec, 2020 


\section{CONCLUSIONS}

In view of the results found for the fruits of Physalis pubescens $L$., it was observed that these fruits are a significant source of bioactive compounds such as carotenoids and phenolic compounds, mainly in the pulp fraction, and therefore can be used by the food and pharmaceutical industries.

Furthermore, after proximal analysis, the fruits showed nutritional potential, being sources of carbohydrates and lipids, with high potential for insertion in human food.

As it is an acidic fruit, its ingestion in its natural form may be limited, but the insertion of these fruits in preparations or through derived foods is an excellent alternative for consumption.

Physalis pubescens $L$. is an unconventional food plant, being this species still little explored in Brazil, but with the results of this study we can emphasize the health benefits of these fruits so that they may become part of our diet.

\section{ACKNOWLEDGEMENTS, FINANCIAL SUPPORT AND FULL DISCLOSURE}

We would like to thank the Coordination for the Improvement of Higher Education Personnel (CAPES) and the Brazilian National Council for Scientific and Technological Development (CNPq) for supporting the research. The authors also declare that there is no conflict of interest in the research and publication of the manuscript.

\section{REFERENCES}

Antunes FAJ (2016) Estudo da capacidade antioxidante da physalis e revisão da sua aplicação na área da saúde. Dissertação de Mestrado. Instituto Superior de Ciências da Saúde Egas Moniz, Monte da Caparica. 99p.

AOAC (2012) Official Methods of Analysis of AOAC international. $19^{\text {th }}$ ed. Gaithersburg, AOAC International. 3000p.

Bligh EG \& Dyer WJ (1959) A rapid method of total lipid extraction and purification. Canadian Journal of Biochemistry and Physiology, 37:911-917.

Brasil (2003) Resolução RDC n. 360, de 23 de dezembro de 2003 Aprova o Regulamento Técnico sobre Rotulagem Nutricional de Alimentos Embalados, tornando obrigatória a rotulagem nutricional. DOU, 22/12/2000, Seção 1, p.33.

Chinese Pharmacopoeia Commission (2010) Pharmacopoeia of the People's Republic of China. Beijing, People's Medicine Publishing. p.392-393.

Chitarra MIF \& Chitarra AB (2005) Pós-colheita de frutas e hortaliças: Fisiologia e manuseio. $2^{\text {nd }}$ ed. Lavras, Editora UFLA. $783 \mathrm{p}$.

Correia P, Guiné R, Gonçalves F \& Oliveira S (2017) Analysis of some chemical components, phenolic compounds and antioxidant activity in physalis. In: Evita Straumite (Ed.) Abstract Book Procedings of $11^{\text {th }}$ Baltic Conference on Food Science and Technology "Foodbalt 2017". Jelgava, Leeds University Union/Latvia University of Agriculture. 42p.
Curi PN, Carvalho CDS, Salgado DL, Pio R, Silva DFD, Pinheiro ACM \& Souza VRD (2018) Characterization of different native american physalis species and evaluation of their processing potential as jelly in combination with brie-type cheese. Food Science and Technology, 38:112-119.

de Almeida Siqueira EM, Rosa FR, Fustinoni AM, de Sant'Ana LP \& Arruda SF (2013) Brazilian savanna fruits contain higher bioactive compounds content and higher antioxidant activity relative to the conventional red delicious apple. PloS One, 8:e72826.

Deng KJ, Zang LL, Lan XH, Zhong ZH, Xiong BQ, Zhang Y \& Zheng XL (2016) Antioxidant Components from Cape Gooseberry. Journal of Food Processing and Preservation, 40:893-898.

El Sheikha AF (2004) Technological, chemical and microbiological studies on some packed foods. Dissertação de Mestrado. Minufiya University, Xibin El Kom. 174p.

El Sheikha AF, Zaki M, Bakr A, El Habashy M \& Montet D (2008) Physico-chemical properties and biochemical composition of Physalis (Physalis pubescens L.) fruits. Food, 2:124-130.

El Sheikha AF, Ribeyre F, Larroque M, Reynes M \& Montet D (2009) Quality of physalis (Physalis pubescenss L.) juice packaged in glass bottles and flexible laminated packs during storage at $5{ }^{\circ} \mathrm{C}$. African Journal of Food, Agriculture, Nutrition and Development, 9:1388-1405.

El Sheikha A (2010) Détermination de l'origine géographique des fruits du Karité et du Physalis par l'utilisation d'empreintes génétiques sur la communauté microbienne par PCR/DGGE. Tese de Doutorado. Universidade Montpellier 2, Montpellier. 229p.

El Sheikha AF, Zaki MS, Bakr AA, El Habashy MM \& Montet D (2010) Biochemical and sensory quality of Physalis (Physalis pubescens L.) juice. Journal of food processing and preservation, 34:541-555.

Fernandes AC, de Souza AC, Ramos CL, Pereira AA, Schwan RF \& Dias DR (2019) Sensorial, antioxidant and antimicrobial evaluation of vinegars from surpluses of Physalis (Physalis pubescens L.) and red pitahaya (Hylocereus monacanthus). Journal of the Science of Food and Agriculture, 99:2267-2274.

Flóres R, Víctor J, Fischer G, Sora R \& Ángel D (2000) Producción, poscosecha y exportación de la uchuva (Physalis peruviana L.). $1^{\text {st }}$ ed. Bogotá, Universidad Nacional de Colombia. 171p.

Hassanien MFR (2011) Physalis peruviana: a rich source of bioactive phytochemicals for functional foods and pharmaceuticals. Food Reviews International, 27:259-273.

Joshi K \& Joshi I (2016) Effect of Blanching on Nutritional Composition of Effect of Blanching on Nutritional Composition of Rasbhari (Physalis peruviana) Fruit. The IIS University/ Journal of Science \& Techonology, 5:29-33.

Kharchoufi S, Gomez J, Lasanta C, Castro R, Sainz F \& Hamdi M (2018) Benchmarking laboratory scale pomegranate vinegar against commercial wine vinegars: antioxidant activity and chemical composition. Journal of the Science of Food and Agriculture, 98:4749-4758.

Мамедов МИ, Енгалычев МР \& Джос ЕА (2017) Морфобиологические особенности и биохимический состав ягод физалиса пушистого (Physalis pubescens L.) в умеренном климате. Овощи России, 2:76-80.

Mazza G, Fukumoto L, Delaquis P, Girard B \& Ewert B (1999) Anthocyanins, phenolics, and color of Cabernet franc, Merlot, and Pinot noir wines from British Columbia. Journal of Agricultural and Food Chemistry, 47:4009-4017. 
Montet D, Le Nguyen DD, El Sheikha A, Condur A, Metayer I \& Loiseau G (2008) Application of PCR-DGGE in determining food origin: Cases studies of fish and fruits. Aspects of Applied Biology, 87:11-22.

Monteiro A (2009) Valor nutricional de partes convencionais e não convencionais de frutas e hortaliças. Dissertação de Mestrado. Universidade Estadual Paulista, Botucatu. 62p.

National Research Council (1989) Recommended Dietary Allowances. $10^{\text {th }}$ ed. Washington, The National Academies Press. 302 p.

Oliveira JAR, Martins LDS, de Vasconcelos MAM, Pena RDS \& Carvalho AV (2011) Physical, physico-chemical and technological potential of camapu fruits (Physalis angulata). Revista Brasileira de Tecnologia Agroindustrial, 5:573-583.

Osorio DDL \& Roldan G (2003) Volvamos al campo: Manual de la uchuva. Bogotá, Grupo Latino. 36p.

Puente LA, Pinto-Muñoz CA, Castro ES \& Cortés M (2011) Physalis peruviana Linnaeus, the multiple properties of a highly functional fruit: A review. Food Research International, 44:17331740 .

Ramadan MF \& Mörsel JT (2003) Oil goldenberry (Physalis peruviana L.). Journal of Agricultural and Food Chemistry, 51:969-974.

Ramadan MF (2011) Bioactive phytochemicals, nutritional value, and functional properties of cape gooseberry (Physalis peruviana): An overview. Food research international, 44:18301836.

Repo de CR \& Encina ZCR (2008) Determinación de la capacidad antioxidante y compuestos bioactivos de frutas nativas peruanas. Revista de la Sociedad Química del Perú, 74:108-124.

Resende JD, Morales RGF, Faria MV, Rissini ALL, Camargo LK \& Camargo CK (2010) Yield and soluble solids contents of fruits of strawberry cultivars in protected cultivation. Horticultura Brasileira, 28:185-189.

Rockenbach II, Rodrigues E, Cataneo C, Gonzaga LV, Lima A, Mancini-Filho J \& Fett R (2009) Ácidos fenólicos e atividade antioxidante em fruto de Physalis peruviana L. Alimentos e Nutrição Araraquara, 19:271-276.

Rodriguez-Amaya DB (2001) A guide to carotenoid analysis in foods. Washington, Internacional Life Sciences Institute Press. $64 \mathrm{p}$.

Rufato ADR, Rufato L, Lima CSM \& Muniz J (2013) A cultura da Physalis. In: Série Fruticultura (Ed.2). Pequenas Frutas. Florianópolis, Universidade do Estado de Santa Catarina. p.143193.

Salazar MR, Jones JW, Chaves B \& Cooman A (2008) A model for the potential production and dry matter distribution of Cape gooseberry (Physalis peruviana L.). Scientia Horticulturae, 115:142-148.

Santos KS, Flores EM \& Malcher ET (2017) Caracterização química e atividade antioxidante (in vitro) do fruto do camapú (Physalis peruviana, L.). Revista Ciência e Sociedade, 1:89-102.
Sapata KB, Fayh APT \& Oliveira AD (2006) Effect of prior consumption of carbohydrate on the glycaemia and performance. Revista Brasileira de Medicina do Esporte, 12:189-94.

Silva DFD, Pio R, Soares JDR, Elias HHDS, Villa F, Boas V \& de Barros EV (2016) Light spectrum on the quality of fruits of Physalis species in subtropical area. Bragantia, 75:371-376.

Silva PBD (2013) Qualidade, compostos bioativos e atividade antioxidante de frutos de Physalis sp. Dissertação de Mestrado. Universidade Federal da Paraíba, João Pessoa. 108p.

Singleton VL \& Rossi JA (1965) Colorimetry of total phenolics with phosphomolybdic-phosphotungstic acid reagents. American journal of Enology and Viticulture, 16:144-158.

Soares SE (2002) Ácidos fenólicos como antioxidantes. Revista de nutrição, 15:71-81.

Souza PM, Elias ST, Simeoni LA, de Paula JE, Gomes SM, Guerra ENS, Fonseca YM, Silva EC, Silveira D \& Magalhaes PO (2012) Plants from Brazilian Cerrado with potent tyrosinase inhibitory activity. PLoS One, 7:e48589.

Valdenegro M, Fuentes L, Herrera R \& Moya-León MA (2012) Changes in antioxidant capacity during development and ripening of goldenberry (Physalis peruviana L.) fruit and in response to 1-methylcyclopropene treatment. Postharvest biology and technology, 67:110-117.

Vallilo MI, Moreno PRH, de Oliveira E, Lamardo LCA \& Garbelotti ML (2008) Chemical composition of Campomanesia xanthocarpa Berg - Myrtaceae Fruit. Ciência e Tecnologia de Alimentos, 28:231-237.

Vasco C, Ruales J \& Kamal-Eldin A (2008) Total phenolic compounds and antioxidant capacities of major fruits from Ecuador. Food Chemistry, 111:816-823.

Vendramini ALA \& Trugo LC (2004) Phenolic compounds in acerola fruit (Malpighia punicifolia L.). Journal of the Brazilian Chemical Society, 15:664-668

Vizzotto M (2012) Propriedades funcionais das pequenas frutas. Informe Agropecuário, 33:96-103.

Yıldız G, İzli N, Ünal H \& Uylaşer V (2015) Physical and chemical characteristics of goldenberry fruit (Physalis peruviana L.). Journal of food science and technology, 52:2320-2327.

Wen X, Hempel J, Schweiggert RM, Ni Y \& Carle R (2017) Carotenoids and carotenoid esters of red and yellow Physalis (Physalis alkekengi L. and P. pubescens L.) fruits and calyces. Journal of agricultural and food chemistry, 65:61406151.

Zambiazi RC (2010) Análise físico-química de alimentos. Pelotas, Editora Universitária/UFPEL. 202p.

Zavaleta J, Muñoz AM, Blanco T, Alvarado-Ortiz C \& Loja B (2005) Antioxidant capacity and main phenollc acids and flavonoids of some foods. Acta Médica San Martiniana, 1:8185 